\title{
PSYCHOSOCIAL SUPPORT OF EDUCATIONAL PROCESS PARTICIPANTS AT INSTITUTIONS OF VOCATIONAL EDUCATION
}

\author{
Iryna Tkachuk ${ }^{1}$, Yurii Lutsenko², \\ $1 \mathrm{PhD}$ in Pedagogy, Head of the Laboratory of Applied Psychology of Education Ukrainian Scientific and Methodological \\ Center of practical psychology and social work of NAES of Ukraine \\ http://orcid.org/0000-0002-3099-3491 \\ e-mail: irinatkachuk3@gmail.com \\ 2 Researcher Laboratory of Applied Psychology of Education of Ukrainian Scientific and Methodological Center of practical \\ psychology and social work of NAES of Ukraine \\ https://orcid.org/0000-0003-2348-6624 \\ e-mail: yuriy_lko@ukr.net
}

\begin{abstract}
The article analyzes the scientific sources on the problem of psychosocial help to victims of traumatic events, identifies three main approaches to its implementation. The objective of psychosocial support of the educational process participants at the institutions of vocational education who have survived a crisis life event is formulated. It is to promote the preservation of a person in the status of a productive subject of activity, personality and individuality, capable of positive interaction with the world, people and himself. The defined goal is achieved by solving the following tasks: promoting the stabilization of the emotional state and rational perception of one's life situation; formation of constructive ways of solving the complex life situations; activization of processes of self-knowledge, self-perception, self-regulation and self-control; assisting in creation of a positive image of the future; assistance in taking responsibility for own future; development of social competence and social activity, mastering strategies of successful behavior; the formation of a focus on personal development and social realization. To achieve the identified goals and objectives, training programs for psychosocial support for students and teachers of vocational education institutions have been developed.

The training program for students "Reference Point" is aimed at forming their psychological stability in overcoming the consequences of crisis events, increasing the level of stress resistance, training methods for selfrecovery. The program has three components: personal, social, practical.

The program for pedagogical workers consists of two modules. The first module is aimed at the formation of the competence of teachers in providing psychosocial support to students; the second one- to reduce their level of professional burnout. The indicated programs were piloted on the basis of five vocational education institutions of the Donetsk region.
\end{abstract}

Keywords: vocational education institutions, psychosocial support, viability/stress resistance, training program.

Introduction. The urgency of psychosocial support for the educational process participants at vocational education institutions is due to many factors. First of all, it is an armed conflict in the east of the state and the associated psychological traumatism for both adults and children. In addition, a significant part of the contingent of students of vocational education establishments is influenced by other psycho-traumatic circumstances: a certain percentage of them are children from families where parents are deprived of parental rights, pedagogically abandoned students, adolescents with manifestations of deviant and delinquent behavior. Therefore, it is important to develop modern methods and technologies of psychosocial support for the educational process participants at the vocational education institutions.

Materials. An analysis of the world practice of organizing psychosocial help for victims of traumatic 
events and scientific research on the above-mentioned problem has made it possible to distinguish between three main directions that differ from each other by the fact that researchers focus their attention on the different effects of the traumatic event on the person.

Traumatic stress and mental disorders triggered by traumatic events are in the center of attention by the representatives of the first direction (A. Allen, A. Wenger, D. Johnson, V. Dubrovin, S. Ilyin, M. Mazur, I. Malkina-Pich, Yu. Semenov, D. Smith, I. Mamaychuk, N. Tarabrin, K. Horney, C. FleckHopson, V. Fruy, etc.). Summarizing numerous studies in the field of traumatic stress, N. Tarabrin (2001, pp. 15-16) defines it as: stress becomes traumatic, when the result of its influence is a violation in the mental sphere, which occurs in analogy to physical disorders. This violates the structure of "self", the cognitive model of the world, the affective sphere, neurological mechanisms that control the learning process, the memory system, emotional learning pathways. Traumatic events - extreme crisis situations that have a potentially negative consequence, situations of life threatening for yourself or relatives are in the role of a stressor in such cases. Such events violate the individual's sense of security radically, causing the experience of traumatic stress, psychological consequences of which are diverse. The fact of experiencing traumatic stress for some people becomes a reason of their post-traumatic stress disorder emergence, in the future. Its authors define it as nonpsychotic delayed reaction to traumatic stress, that can cause mental disorders in any person.

Representatives of the second direction (S. Bogdanov, R. Gjstad, E. Diregrov, S. Perrin, G. Selye, P. Smith, A. Timchenko, V. Chornobrovkina, T. Yatsenko, etc.) focus on the ability of a person to resist action of stressors. In the framework of this trend, the concept of resilience was introduced in the studies of foreign scientists. In the psychological sense, resiliency is understood as the ability of a person to resist the actions of stressors without getting into a state associated with mental disorders (Bogdanov et al., 2017, pp. 12-15).

Representatives of the third direction focus their attention on those positive changes that arise in person as a result of crisis trials (L. Kalhoun, K. McGonigall V. Panok, R. Tedeschi, T. Titarenko, etc.). The concept of "posttraumatic growth" is due to its emergence of R. Tedeschi and L. Calhoun (Tedeschi and Calhoun, 2004). Researchers describe it as a situation in which the development of personality, at least in some areas, after a crisis life event exceeded the level that was before the crisis. That is, a person not only returned to the initial state, but also improved himself in some important areas.
The purpose of the paper is to determine the purpose and objectives of the psychosocial support of the educational process participants, who have survived crisis life events; provide training programs for psychosocial support for students and teachers of vocational education institutions.

Methods: theoretical and methodological analysis, systematization and generalization of psychological and pedagogical sources for determining the goals and objectives of psychosocial support for the educational process participants; questionnaires, interviews, expert pedagogical assessment, focused group interviews to check the effectiveness of the developed training programs and to clarify the content of individual training lessons.

Results and discussions. The analysis of scientific sources and the generalization of the four-year experience of psychological service workers in providing psychosocial assistance to children who survived crisis life events allowed to determine the purpose and tasks of providing psychosocial assistance to children of the specified category in the conditions of an educational institution.

Consequently, the main purpose of the implementation of psychosocial assistance to a student who survived crisis life events, is to promote his preservation in the status of a productive subject of activity, personality and individuality, capable of positive interaction with the world, people and himself.

The defined goal is achieved by solving such problems in work with the students: (Tkachuk, 2018; Muzychenko and Tkachuk, 2017): promoting stabilization of the emotional state and rational perception of one's life situation; formation of constructive ways of solving complex life situations; activization of processes of self-knowledge, selfperception, self-regulation and self-control; assisting in building a positive image of the future; assistance in taking responsibility for own future; development of social competence and social activity, mastering strategies of successful behavior; the formation of a focus on personal development and social realization.

Psychosocial support for students who have survived a psychotrauma must be based on the principles tested by the experience of psychological assistance to victims of traumatic events, which are constantly updated and supplemented in accordance with the development of this area of psychological practice.

Basic principles are:

1. Principle of orientation to personal growth and development. The crisis situation in which there is a student, should be considered not as a disease or pathology, but as a normal reaction of the individual to abnormal circumstances. In addition, the crisis $-\mathrm{a}$ process of personal formation, and if it is to overcome 
positively, then the person goes to a qualitatively new stage of development. Proceeding from this, psychosocial support can be considered as aiding the process of personal formation of the student.

2. Principle of unconditional positive attention. The basis for communicating with students should be mutual trust and respect. It is important that during the process of correction-development work, a safe atmosphere is created that is favorable for selfexpression and disclosure of the student. It can be only achieved if you accept the personality as she is. If the circumstances require correction of the destructive behavior of the student, the behavior, deed is only evaluated (not his personality).

3. The principle of taking into account age characteristics. The specifics of the work should be differentiated according to the age-specific characteristics of the students (to be taken into account: psycho-physical development, the leading form of activity, the interests of the student).

4. Principle of community orientation. It is important to take into account the social environment when working with pupils' problems, and they should be considered as part of the overall situation. Thus, it is necessary to work not only with students, but also with their parents, relatives, teachers, etc.

5. Principle of multiplicity of work. Any corrective action should be oriented at all levels of student's functioning: behavior, skills, emotions, cognitive processes, system of values, system of beliefs, personal identity, "I-concept". Such a multiplicity and complex nature contribute to the full development of the process of constructive change.

6. Multidisciplinary principal. Based on a wide range of the identified tasks and objectives, work requires a multidisciplinary approach. To work with students who have survived a crisis, not only employees of the psychological service, but also other employees of the educational institution should be involved.

7. Principle of prolongation and sequence of work. Such work goals as overcoming traumatic experience, promoting psycho-physical development and ensuring the student's personal formation require a prolonged work (not less than one year) of work, rather than onetime interventions. During this time the student must pass a cycle of specially selected correctiondevelopment programs. Each subsequent program will deepen and enrich the learner's skills in the previous program, skills and experience.

8. Principle of integration with society. Rehabilitation intervention should be aimed at the formation of students as productive members of a society with an active civic position (Beberashvili, Javakhishvili, Mahashvili and Sargwelladze, 2001, p. 25).
In order to implement the defined content and performance of the planned tasks, the staff of the Ukrainian Scientific and Methodological Center of Practical Psychology and Social Work, in cooperation with the Danish Refugee Council in Ukraine, developed training programs for psychosocial support for the educational process participants of vocational education institutions.

The training program for students "Reference Point" is aimed at forming their psychological stability in overcoming the consequences of crisis events, increasing the level of stress resistance, training methods for self-recovery. The program has three interrelated and equivalent components: personal (understanding of oneself, strengths and weaknesses, familiarity with emotions and feelings, etc.), social (ability to live with others, resolve conflicts, etc.), practical (building life plans, etc.) .

Contents of the program of psychosocial support for students of vocational education institutions:

Session 1. Introduction. Acquaintance.

Session 2. Important life skills.

Session 3. Important life skills: the ability to say "no" in a risky situation.

Session 4. Important Life Skills: Understanding Conflict.

Session 5. Important life skills: we resolve conflicts taking into account the positions of the parties.

Session 6. Events and feelings.

Session 7. Feelings and emotions. Anger management.

Session 8. Who am I? Which am I?

Session 9. On the way to success.

Session 10. Team.

Session 11. Health is my treasure.

Session 12. Reference Point.

In order to clarify the content of individual lessons of the proposed program in 2016, a number of focused group interviews were conducted at vocational education institutions of the Donetsk region. An analysis of the results of group interviews made it possible to draw a number of conclusions.

The ability to manage own emotions is an important life skill, defined by students. They rated independently the level of their formation as low one, because it is the most difficult for them to restrain anger, aggression, rage Most of the respondents can not, actually, identify and name their feelings in a particular situation. In addition, it is difficult for them to "read" the emotions of another person, which negatively affects the establishment of constructive relationships. Young people (15-19 years old) often overcome the consequences of stress and negative situations by destructive ways - using alcohol.

Students also mentioned that they would like to have conflict resolution skills. In their responses, they 
confirmed quite frequent cases of conflicts with parents, in training groups, dormitories, and so on.

Another important life skill is the ability of students to overcome obstacles and difficulties. However, about half of respondents said that in the face of problems, they usually avoid solving such situations.

Defining the necessity and usefulness of a healthy lifestyle, more than half of the participants in the focus group noted that they care for their health badly. In determining the causes of irresponsible attitude to health, students demonstrated the asymmetry of the attributive style in favor of external, independent circumstances (eg, ecology, etc.), in contrast to their activity in overcoming complications and obstacles.

Among the life goals, students point out: good work, high salary, a strong family, a career, self-realization. Unfortunately, the interviewed students do not see any prospects for employment in their place of residence. A certain number says about going abroad for this purpose. Among the skills to organize their own leisure, the respondents indicated their work at the computer, watching TV. Skills of self-presentation, writing a resume, conducting interviews with potential employers are not well developed.

The skills of farming, cleaning, maintaining lifestyle are also poorly developed. The vast majority of them are not able to search and interact with certain utilities (energy, water supply, gas, etc.), fill in receipts and pay bills. Almost all agreed that they are not able to plan a budget and spend their money wisely.

The proposed training program was tested on the basis of five pilot vocational education institutions of the Donetsk region. An analysis of the results of the input / output survey of the participants of the program allows us to make a conclusion about the increase of their stress tolerance, improvement of mood and wellbeing, in general. Participants noted positive changes in peer relationships in educational groups, with teachers and parents. The fact of the motivation changes to participate in the training is also interesting. If at the beginning we had to explain the participants, in detail, what the training is to be for and what will happen, then, in the course of the work of the training groups, the number of people willing to take part into the program has increased dramatically. It may also indicate an increase in confidence in adults, including teachers. Based on the recommendations of the participants, the training program has been expanded. In particular, the theme "Health" was developed in addition and the number of hours for the "Conflict" topic was increased.

The training program of psychosocial support for teachers of vocational education establishments consists of two modules: the formation of competencies regarding the provision of psychosocial support to students and their parents; psychosocial support of pedagogical workers in conditions of the educational institution, aimed at reducing the level of professional burnout.

The content of the first module involves the inclusion of such issues for working with educators: how children react to a crisis event; the role of a teacher in supporting psychosocial well-being of students; how to discuss issues of crisis (events) with students; the actions of pedagogical workers aimed at the rehabilitation of students; management of changeable behavior and support of positive discipline; identification and support of children in need of enhanced support.

The second module includes the following topics: "Psychosocial well-being and its components", "Ways of supporting the psychosocial well-being of teachers", "Methods of recovery and prevention", "Burnout: reasons, indicators, methods of recovery and prevention", "Conflict", "Support of psychosocial wellbeing of students" (Beberashvili, Javakhishvili, Mahashvili and Sargwelladze, 2001, p. 25 Kornienko, Lisovetska, Lutsenko Romanovska, 2017, pp. 125152).

The indicated programs also went on piloting on the basis of five vocational education institutions of the Donetsk region and was discussed during the round table "Psychosocial support of participants in the educational process at the vocational institution" in June 2017. The program received positive reviews from its own trainers, heads of educational institutions, participants of the training course. The introduction of the training provided an assessment of its effectiveness by comparing the results of the input / output survey of the participants. At the start of the stage, the following reactions were observed in pedagogical staff: tightness, misunderstanding of the essence of the new format of work, comments about active colleagues, low motivation to participate in the training, etc. However, in the process of work there were significant changes in the level of motivation of teaching staff to participate in the training, their activity at the classes, as well as the degree of inclusion into the training process. The dynamics of changes in the degree of inclusion of pedagogical staff of vocational education pilot institutions into the training process is illustrated in Table 1

The trainers noted that this dynamics became visible from the third meeting: teachers began to talk about themselves, and not just about students, showed openness in discussing the individual topics, ways to react to events related to the military conflict, shared practical ways to self-renewal in crisis / stress situation. The topic of professional burnout and methods of its prevention became particularly interesting for the teachers. 
The dynamics of changes in the degree of inclusion of teaching staff of pilot vocational education institutions into the training process (amount / interest.) staff into the training process
Levels of inclusion of teaching

The total amount of teaching staff, who took part in the training program

\begin{tabular}{cccc}
\hline & Input survey & Output survey & Dynamics \\
\hline High & $8 / 9 \%$ & $42 / 49 \%$ & $+40 \%$ \\
\hline Medium & $29 / 34 \%$ & $25 / 29 \%$ & $-5 \%$ \\
\hline Low & $49 / 57 \%$ & $19 / 22 \%$ & $-35 \%$ \\
\hline
\end{tabular}

Conclusions. It is determined that the problem of psychosocial support of the educational process participants at vocational education institutions is relevant, especially in the eastern regions of the country, which are close to the zone of combat operations. Its purpose is to promote the preservation of a person in the status of a productive subject of activity, personality and individuality, capable of positive interaction with the world, people and himself. In order to organize the psychosocial support of educational process participants at the institutions of vocational education, a training program for students was developed and tested. The program is aimed at forming their psychological stability in overcoming the consequences of crisis events, increasing the level of stress resistance, training ways to self-recovery. It is shown that the program has three interrelated and equivalent components: personal (understanding of oneself, strengths and weaknesses, familiarity with emotions and feelings, etc.), social (the ability to live with others, solve conflicts, etc.), practical (creation of life plans, etc.).

The program for pedagogical workers consists of two modules. The first module is aimed at educating pedagogical staff in providing psychosocial support to students; the second - to reduce their level of professional burnout.

The presented program does not exhaust all the necessary aspects of psychosocial support for the educational process participants at the vocational education institutions. Further research requires the creation of a technology for psychosocial support for the educational process participants, which involves co-operation and coordination of efforts of teachers, parents and all institutions involved in the organization to help people in crisis situations.

\section{List of references}

Беберашвили, 3., Джавахишвили, Д., Махашвили, Н. и Сарджвеладзе, Н., 2001. Травма и психосоииальная помощь. Практическое руководство, основанное на опыте НПО Грузии. Тбилиси; Баку: Норвежский Совет по беженцам.

Богданов, С. О. та ін. Чернобровкін, В.М. та Панок, В. Г., ред., 2017. Підготовка вчителів до розвитку житmєстійкості/стресостійкості у дітей в освітніх навчальних закладах : навч.-метод. посіб. Київ : ПУЛЬСАРИ.

Корнієнко, І. О., Лісовецька І. М., Луценко Ю. А., Романовська Д. Д., 2017. Досвід надання допомоги дітям і сім'ям - жертвам військового конфлікту: практ. посіб. Київ : УНМЦ практичної психології і соціальної роботи.

Музиченко, I. В. та Ткачук, I. I., 2017. Шляхи подолання дитячої психотравми в діяльності працівників психологічної служби: методичні рекомендації. Київ: УНМЦ практичної психології і соціальної роботи.

Тарабрина, Н. В., 2001. Практикум по психологии посттравматического стресса. СПб : Питер.

Ткачук, I. I., 2018. Психолого-педагогічний супровід особистісного і професійного самовизначення стариокласників, щуо опинилися у складних життєвих обставинах внаслідок військових конфліктів. Київ: УНМЦ практичної психології і соціальної роботи, 2018.

Tedeschi, R.G. and Calhoun, L.G., 2004. Posttraumatic Growth: conceptual foundations and empirical evidence. Psychological Inquairy, 15 (1), s. 1-18.

\section{Translated \& Transliterated}

Beberashvili, Z., Dzhavahishvili, D., Mahashvili, N. i Sardzhveladze, N., 2001. Travma i psihosotsialnaya pomosch. Prakticheskoe rukovodstvo, osnovannoe na opyite NPO Gruzii [Injury and psychosocial assistance. Practical guide based on the experience of NGOs in Georgia]. Tbilisi; Baku: Norvezhskiy Sovet po Bezhentsam, [in Russian].

Bohdanov, S. O. ta in. Chernobrovkin, V.M. ta Panok, V. H., red., 2017. Pidhotovka vchyteliv do rozvytku zhyttiestiikosti/ stresostiikosti u ditei v osvitnikh navchalnykh zakladakh: navch.-metod. Posibnyk [Teacher training for development of vitality/stress resistance of children at the educational institutions]. Kyiv: PULSARY, [in Ukrainian].

Kornienko, I. O., Lisovetska I. M., Lutsenko Yu. A., Romanovska D. D., 2017. Dosvid nadannia dopomohy ditiam $i$ simiam - zhertvam viiskovoho konfliktu: prakt. posib [The experience of helping children and families - victims of a military conflict]. Kyiv: UNMTs praktychnoi psykholohii i sotsialnoi roboty, [in Ukrainian]. 
Muzychenko, I.V. ta Tkachuk, I. I., 2017. Shliakhy podolannia dytiachoi psykhotravmy v diialnosti pratsivnykiv psykholohichnoi sluzhby: metodychni rekomendatsii [Ways to overcome the psychological children's trauma in the activities of workers of psychological services]. Kyiv: UNMTs praktychnoi psykholohii i sotsialnoi roboty, [in Ukrainian].

Tarabrina, N.V., 2001. Praktikum po psihologii posttravmaticheskogo stressa [Practicum on the psychology of posttraumatic stress]. SPb: Piter, [in Russian].

Tkachuk, I.I., 2018. Psykholoho-pedahohichnyi suprovid osobystisnoho i profesiinoho samovyznachennia starshoklasnykiv, shcho opynylysia u skladnykh zhyttievykh obstavynakh vnaslidok viiskovykh konfliktiv [Psychological and pedagogical support of personal and professional self-determination of high school students who find themselves in difficult life circumstances as a result of military conflicts]. Kyiv: UNMTs praktychnoi psykholohii i sotsialnoi roboty, 2018, [in Ukrainian].

Tedeschi, R.G. and Calhoun, L.G., 2004. Posttraumatic Growth: conceptual foundations and empirical evidence. Psychological Inquairy, 15 (1), s. 1-18, [in English].

УДК 377-05:[364:159.9]

\section{Психосоціальна підтримка учасників освітнього процесу в закладах професійної освіти}

Ірина Ткачук ${ }^{1}$ Юрій Луценко ${ }^{2}$,

1 кандидат педагогічних наук, завідувач лабораторії прикладної психології освіти, Український науково-методичний центр практичної психології і соціальної роботи НАПН України http://orcid.org/http://orcid.org/0000-0002-3099-3491

e-mail: irinatkachuk3@gmail.com

2 науковий співробітник лабораторії прикладної психології освіти, Український науково-методичний центр практичної психології і соціальної роботи НАПН України

http://orcid.org/https://orcid.org/0000-0003-2348-6624

e-mail: yuriy_lko@ukr.net

Реферат. У статті проаналізовано наукові джерела з проблеми психосоціальної допомоги постраждалим від травматичних подій, виділено три основних підходи до здійснення такої. Сформульована мета психосоціальної підтримки учасників освітнього процесу в закладах професійної освіти, що пережили кризову життєву подію. Вона полягає у сприянні збереженню людини в статусі продуктивного суб'єкта діяльності, особистості та індивідуальності, здатної до позитивної взаємодії зі світом, людьми і собою. Визначена мета досягається шляхом вирішення таких завдань: сприяння стабілізації емоційного стану та раціональному сприйняттю своєї життєвої ситуації; формування конструктивних способів вирішення складних життєвих ситуацій; активізація процесів самопізнання, самоприйняття, саморегуляції і самоконтролю; надання допомоги в побудові позитивного образу майбутнього; сприяння прийняттю на себе відповідальності за власне майбутнє; розвиток соціальної компетентності та соціальної активності, оволодіння стратегіями успішної поведінки; формування спрямованості на особистісний розвиток і соціальну реалізацію. Для досягнення визначених мети й завдань розроблено тренінгові програмі психосоціальної підтримки учнів та педагогічних працівників закладів професійної освіти.

Тренінгова програма для учнів "Точка відліку" спрямована на формування в них психологічної стійкості у подоланні наслідків кризових подій, підвищення рівня стресостійкості, навчання способам самовідновлення. Програма має три складники: особистісний, соціальний, практичний.

Програма для педагогічних працівників складається з двох модулів. Перший модуль спрямований на формування у педагогів компетентностей щодо надання психосоціальної підтримки учням; другий - на зниження в них рівня професійного вигорання. Вказані програми пройшли пілотування на базі п'яти закладів професійної освіти Донецької області.

Ключові слова: заклади професійної освіти, психосоціальна підтримка, життєстійкість / стресостійкість, тренінгова програма. 